\title{
Effectively Maintained Inequality in Educational Transitions in the Republic of Ireland
}

American Behavioral Scientist 2017, Vol. 6I (I) 49-73

(c) 2016 SAGE Publications Reprints and permissions: sagepub.com/journalsPermissions.nav DOI: $10.1177 / 000276421668299$ | journals.sagepub.com/home/abs

@SAGE

\section{Delma Byrne' and Selina McCoy²}

\begin{abstract}
While it is well established that the structure and organization of the education system affects youth transitions, less attention has been paid to the study of qualitative distinctions at the same level of education over time in the Irish context. Using data from the School Leavers' Survey over the period 1980-2006, this paper considers the hypothesis of effectively maintained inequality in the case of the Republic of Ireland. The data capture young people's transitions during three distinct and remarkable macro-economic fluctuations, and makes a particularly interesting test case for EMI. Over the cohorts under investigation, Ireland had changed from a recessionary economic climate and prolonged economic stagnation for much of the 1980s to a booming economy by the middle of the mid-2000s and one of the most dynamic economies in the world during the "Celtic Tiger" period. The patterns of social-class inequality over a 30-year paper reported in this article suggest that qualitative differences at the same level of inequality represent a persistent barrier to greater equality in the Irish context. Specifically, we find three notable patterns to support the hypothesis of EMI with regard to tracking decisions taken in the transition from lower secondary to upper secondary, subject-level differentiation in the upper secondary mathematics curriculum, and access to university higher education.
\end{abstract}

\section{Keywords}

Social inequality, effectively maintained inequality, tracking, maths, higher education, Ireland

IThe National University of Ireland, Maynooth, Co. Kildare, Ireland

${ }^{2}$ Economic and Social Research Institute, Dublin, Ireland

\section{Corresponding Author:}

Delma Byrne, Departments of Sociology and Education, The National University of Ireland, Maynooth,

Co. Kildare, Ireland.

Email: delma.byrne@nuim.ie 


\section{Introduction}

Ireland has experienced remarkable educational expansion during the second half of the 20th century by international standards (Organisation for Economic Co-operation and Development, 2013). As in other institutional contexts, increases in rates of participation at upper secondary level and higher education in Ireland have been accompanied by the development of an education system in which new programs, differentiated curricula, and new institutions have emerged. As participation in education rises, it increasingly matters not only how much education people accumulate but also the type of education that is received for later labor market outcomes (Byrne, 2008; McCoy, \& Smyth, 2011; Layte, O’Connell, Fahey, \& McCoy, 2005; Kelly, O'Connell, \& Smyth, 2010). While it is well established that the structure and organization of the education system affects youth transitions in the Irish context (Byrne, 2008, 2009; Byrne, McCoy, \& Watson, 2008; Layte et al., 2005; McCoy, Smyth, Watson, \& Darmody, 2014; McCoy \& Smyth, 2011), less attention has been paid in the Irish context to the study of qualitative distinctions at the same level of education over time, at both secondary and higher education, and how young people from different social-class backgrounds fare.

This article seeks to address these gaps in the literature, and in an exploration of the qualitative distinctions that can be made in education, a key consideration is the hypothesis of effectively maintained inequality (EMI) in the case of the Republic of Ireland. EMI theory argues that qualitative distinctions in education help maintain socioeconomic differences in students' probability of progressing through an educational system. As a result, socioeconomically advantaged but academically equivalent students have a higher likelihood of progressing irrespective of whether a given level of education is (almost) universal in the population (Lucas, 2009).

Using nationally representative data from the regular School Leavers' Survey (SLS) over a 30-year period spanning from 1980 to 2006, this article considers how social-class background shapes the probability that students from diverse backgrounds with similar academic achievements access and complete key transitions in the Irish education system. In doing so, it contributes to the literature by conducting a more detailed educational transition analysis than what currently exists in the Irish context, as it follows academic track students through the education system. In this article, we focus on three key transition points that occur in the Irish educational system from lower secondary education to postschool outcomes, paying particular attention to the detailed set of qualitative distinctions that are offered within each transition. The data capture young people's transitions during remarkable macro-economic fluctuations, and makes a particularly interesting test case for EMI. Over the cohorts under investigation, Ireland had changed from a recessionary economic climate and prolonged economic stagnation for much of the 1980 s to a booming economy by the middle of the 000s and one of the most dynamic economies in the world during the "Celtic Tiger" boom period (see Table 1). Against this backdrop, it is particularly revealing to explore what happed to young people's trajectories through the education system, and to explore the extent to which the hypothesis of EMI is upheld. 


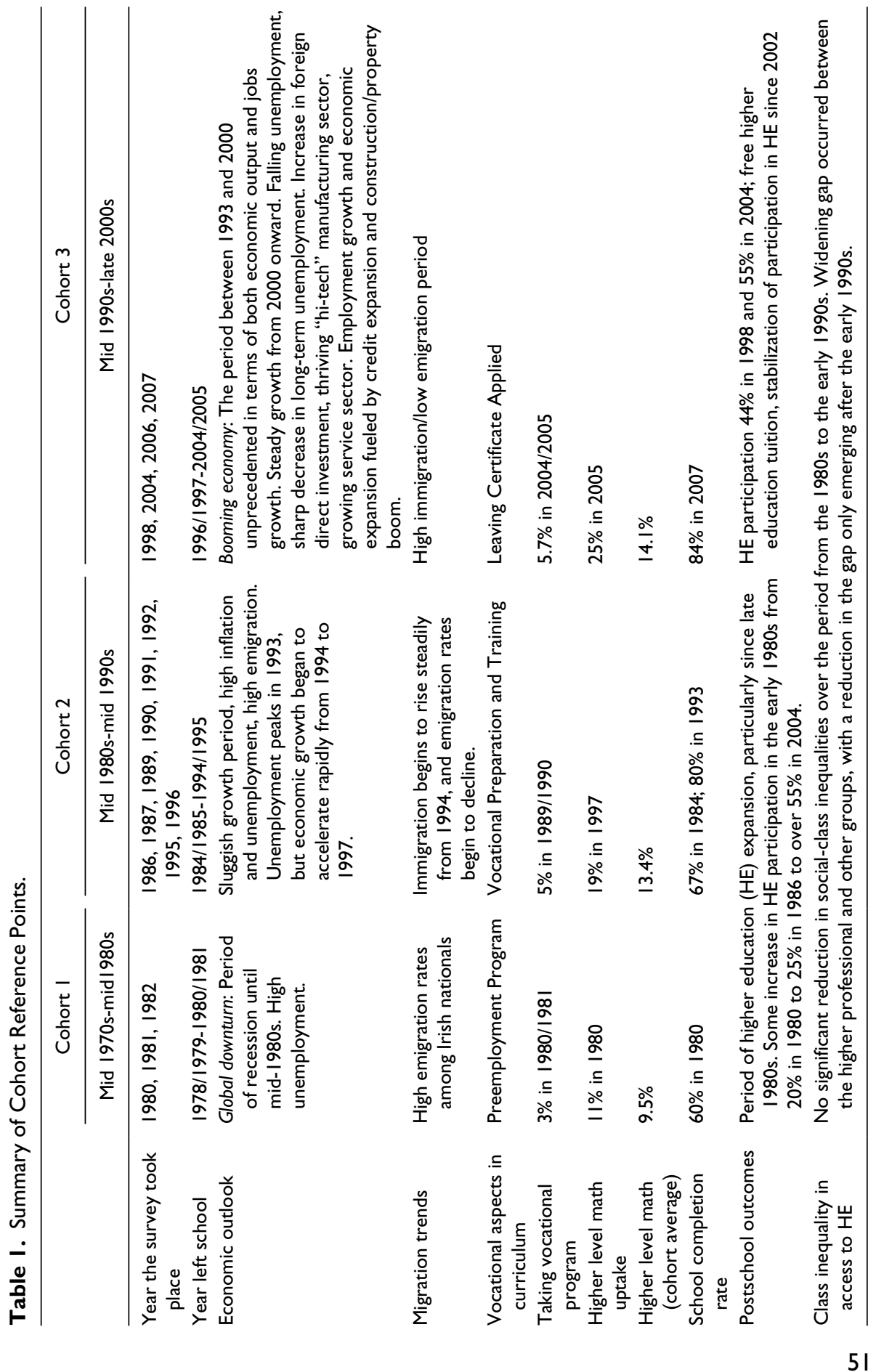


The article is organized as follows. Section 2 provides an overview of research on social stratification in education in Ireland, and the key structural features of the Irish education system which are likely to have implications for social stratification and the maintenance of socioeconomic differences in education. Section 3 then presents an overview of the rich data set that is used - the SLS - as well an overview of the analytic framework. Section 4 presents the results and the final section provides a summary of the conclusion, where we assess and discuss to what extent the EMI hypothesis holds within the current Irish educational system.

\section{The Irish Education System}

Social stratification patterns in educational outcomes across systems can be considered in a context of the logics of capitalism and the structure of welfare states (Mau \& Verwiebe, 2010). In this regard, Ireland represents an interesting case study to consider EMI. A distinctive political economy context, Ireland is classed as an Anglo model welfare state of relatively limited social support and a concentration on means-testing welfare support (Esping-Andersen, 1990) and Anglo American model of capitalism (Hall \& Soskice, 2001). Indeed, more recently, Ireland is similar to some Scandinavian and accession countries, given its low share of early school leaving and high proportion of graduates from second-level and higher education. Furthermore, the linkage between inequalities in income and educational inequalities is pronounced in the Irish context, with higher levels of educational attainment associated with higher earnings and household income and low levels of attainment and skills being predictors of welfare receipt and dependency (Nolan et al., 2014).

Ireland can also be classified as a country whereby the state provides learning environments to a greater extent than the market over the long term (Beblavý, Thum, \& Veselkova, 2013). However, in liberal regimes, it is argued that the "trade-off thesis" holds, whereby social and educational policies compete for public spending support (Pechar \& Anders, 2011). One of the most open economies in the world, O'Riain and O'Connell (2000) note that the Irish state has played a key role in upgrading industry and expanding the educational system. Ireland underwent an "education revolution" (Nolan et al., 2014, p. 354) from the introduction of free compulsory schooling in the 1960s through to the mass expansion of higher education during the 1990s and 2000s. School completion rates had increased substantially over the period (see Table 1). While school dropout rates declined substantially among those from skilled and semiskilled/unskilled working class backgrounds, patterns of school completion continue to be structured by social class, with those from semiunskilled manual backgrounds 2.7 times more likely to do so than those from higher professional backgrounds (Byrne \& Smyth, 2010). ${ }^{1}$ Despite increased levels of higher education participation among all groups, relativities remained between professional/farming groups and nonmanual/ unskilled manual groups, prompting increasing policy focus on widening participation in higher education. A number of studies have concluded that educational expansion has not resulted in any significant reduction in social-class inequalities over the period from the 1980s to the early 1990s (Breen \& Whelan, 1993; McCoy \& Smyth, 2011; 
Smyth, 1999; Whelan \& Layte, 2002). Rather, a widening gap occurred between the higher professional and other groups, with a reduction in the gap only emerging after the early 1990s (McCoy \& Smyth, 2011). While these quantitative differences have been studied in-depth, less explored in the Irish context has been the qualitative distinctions at the same level of education over time.

The time period covered by the data represents young people who left the secondlevel education system between 1978/1979 and 2004/2005. Over this period, there has been considerable change in the number of young people attending and completing second level but also considerable curriculum change. In this article, three main transition points are considered and are discussed below.

First, in the transition from lower secondary to upper secondary, a qualitative distinction is evident in the type of upper secondary education program that students pursue, distinguishing between (a) students following higher status academic programs; (b) those following a lower status prevocational program; and (c) those who do not make the transition to upper secondary education, resulting in qualitative differences. Previous research has considered the effects of curriculum differentiation at upper secondary level on student outcomes and student experiences of schooling (see, e.g., Banks, Byrne, McCoy, \& Smyth, 2010, 2014; Byrne, 2008). However, less attention has been paid to changes over time in the delivery of education, in particular prevocational education and curricula, given the expansion in school attendance, and the evolution of prevocational programs at upper secondary level since the 1970s. In this article, the consequences of curriculum change at upper secondary are assessed, so as to make distinctions between the following versions of (prevocational) programs on offer since the late 1970s, each with their particular aims and orientation ${ }^{2}$ to include (a) Preemployment Programs (mid 1970s-mid1980s), (b) Vocational Preparation and Training Programs (mid 1980s-mid 1990s), and (c) the Leaving Certificate Applied (mid 1990s-present).

Comparative studies of education systems have generally characterized the Irish education system as having an upper secondary education system that is general with little or no differentiation (Hannan, Raffe, \& Smyth, 1997). Furthermore, vocational education tends to be "prevocational" given its low degree of vocational specificity and the overall low standardization of vocational training/education (Hannan et al., 1997). As Figure 1 highlights, the uptake of students in (pre)vocational tracks in upper secondary level has remained relatively stable, not reaching more than $6 \%$ of the cohort at any time. The earliest inception of vocational specificity at this level had considerably lower uptake rates among those leaving school in the late 1970s and early 1980s. As these prevocational programs become more embedded/established in the upper secondary system, we expect to see the hypothesis of EMI to strengthen over each cohort.

Second, among those who make the transition to upper secondary education, a qualitative distinction can be made according to the level of academic challenge at which mathematics is taken, distinguishing between those who took an "honors" or "pass" level paper. While math attainment is a key determinant of higher education entry (McCoy \& Byrne, 2010), limited attention has been paid to social-class differentiation 


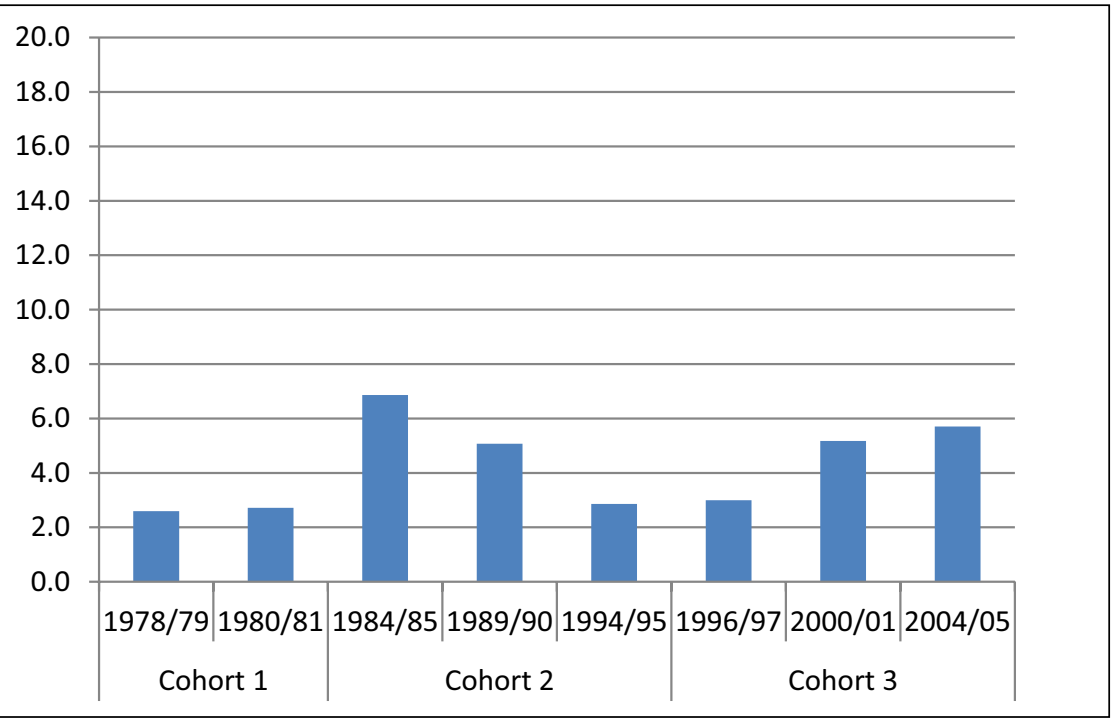

Figure I. Percentage of senior cycle students in school-based (pre)vocational programs, 1978 to 2005.

Note. Adapted from the Department of Education and Skills Historical Statistical Reports. ${ }^{3}$

in the level of math uptake over time. ${ }^{4}$ As Figure 2 illustrates, the percentage of academic track students taking higher level math has steadily increased from $11 \%$ in 1980 to $19 \%$ in 1997 and $25 \%$ in $2005 .{ }^{5}$ These patterns are linked to the economic transformation of Ireland during the 1990s. As employment in agriculture and traditional industrial sectors began to decline, rapid employment growth occurred in newer manufacturing sectors such as electronics, pharmaceuticals and medical instrumentation, construction, tourism, and internationally traded financial sectors. Consideration of the factors associated with the uptake of higher level math across three cohorts over three decades (late 1970s to late 2000s) allows for an examination of the possible stratifying role that subject-level differentiation may play during a period of massive expansion of secondlevel and higher education and expanded labor market skill requirements. As the demand for higher level math increases among employers and higher education providers, and competition for access to higher level math classes increases across schools, we expect to see the hypothesis of EMI to strengthen over each cohort.

Finally, for the transition from school to third level, a qualitative distinction can be found in the type of postcompulsory educational institution that students enter into, distinguishing between those attending universities; institutes of technology and other third-level institutions (colleges); as well as those who do not make the transition to tertiary education. Expansion in postcompulsory educational participation, as in most European countries, has been dramatic, reflecting growth in two distinct higher education sectors (Breen, Luijkx, Muller, \& Pollack, 2009; McCoy \& Smyth, 2011). These 


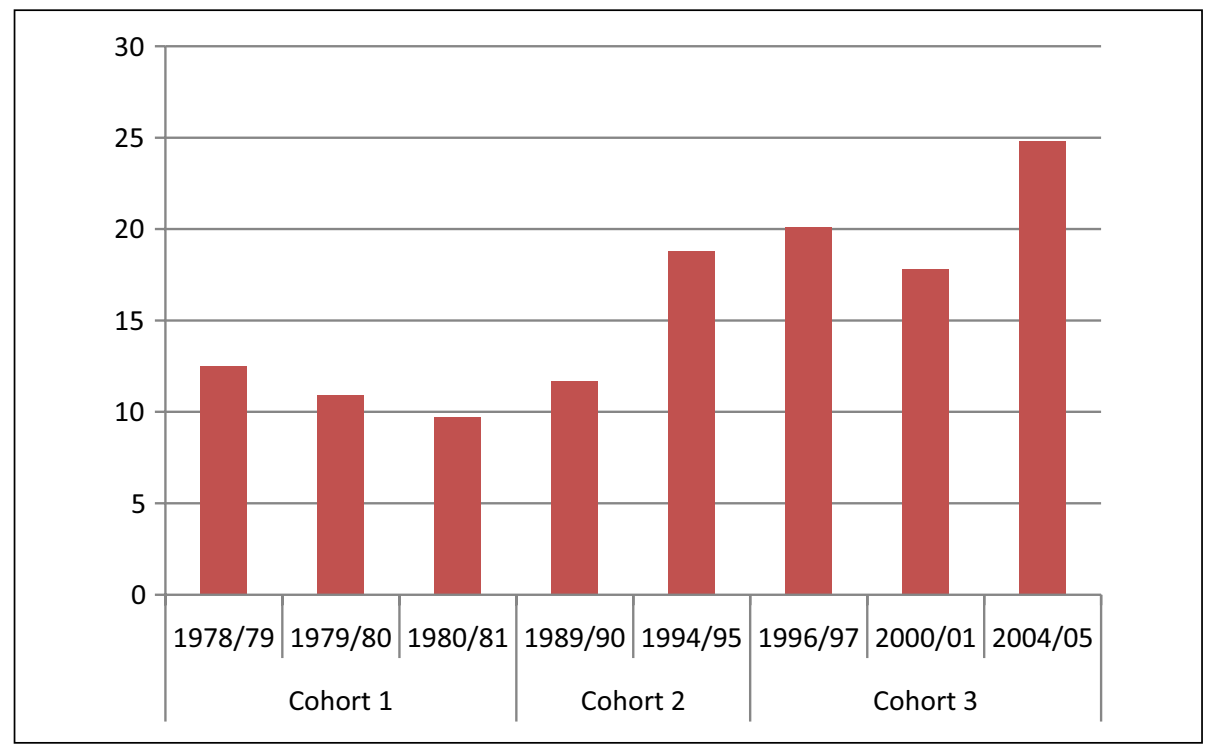

Figure 2. Percentage of academic track students in senior cycle taking higher level math, 1978 to 2005.

sectors, a "first-tier" university sector, the oldest of which dates from the 16th century with a further group of universities established in the 19th century, and "second-tier" institute of technology sector, established in the late 1960s onward. Expansion in the institute of technology sector was greater than that in the university sector; the number of institute of technology places increased by $388 \%$ between 1980 and 2004, while university places increased by $174 \%$ (McCoy \& Smyth, 2011, p. 247).

While previous research has identified that social-class background determines entry to the type of postcompulsory educational institutions that young people attend (see McCoy \& Smyth, 2011), in this article, we seek a greater comparison of like with like, focusing on academic track students with similar academic achievements from diverse backgrounds, and include an examination of the possible stratifying role that subject-level differentiation in math may play. The time period covered by the data represents a dramatic increase in higher education participation, an increase in institution of technology participation, coupled with the removal of higher education tuition fees from 1996, but with limited impact on the reduction of social-class inequalities, as indicated above. We hypothesize that we expect to see the hypothesis of EMI to strengthen over each cohort.

\section{Data and Analytic Strategy}

The data used to test the EMI hypothesis in the case of Ireland are derived from the SLS. The first SLS was carried out on an annual or biennial basis between 1980 and 2007. The 


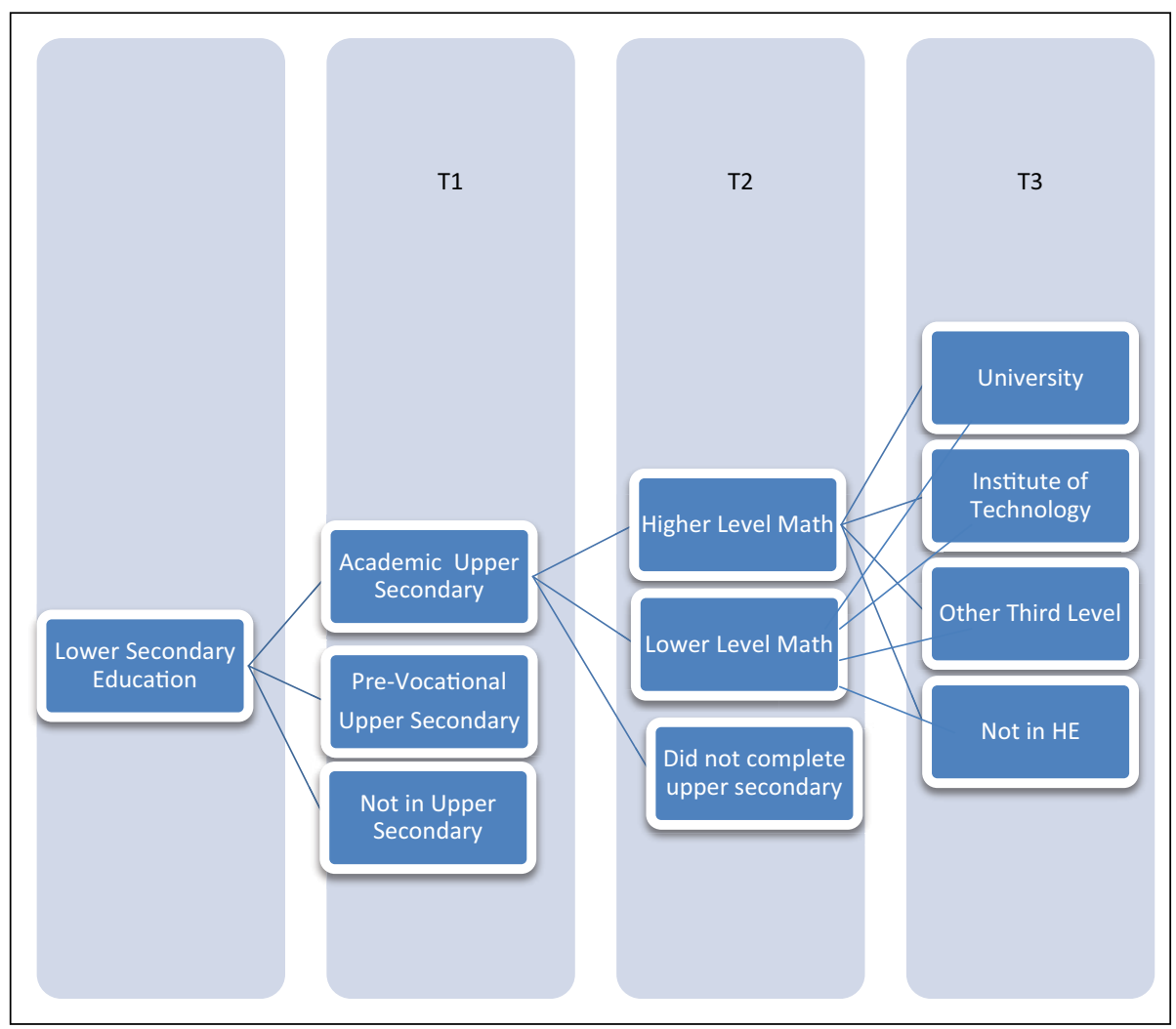

Figure 3. Transition Points Through the Irish Education System.

survey targeted the cohort of young people who left school at all stages during each particular academic year. Thus, data are collected from young people between the ages of 12 and 18 years, depending on the age at which they left school. This is consistent across all cohorts. In all, there are 24 surveys which cover the period from 1978 to 2007, constructed as a time series. This results in a sample of 55,000+ cases. The SLS is a nationally representative survey of young people attending all categories of second-level education with the exception of those attending special schools. The analyses are carried out with a view to highlighting three cohorts: those who left school between 1978 and 1981 (Cohort 1), those who left school between 1984 and 1995 (Cohort 2), and those who left school between 1996 and 2005 (Cohort 3). These time points represent eras of education policy, economic, and curriculum change (see Table 1).

This chapter focuses on three dependent variables, namely:

1. The type of education undertaken beyond junior cycle. This variable distinguishes between (a) students who followed an academic route, (b) those who 
followed a prevocational route, and (iii) those not in upper secondary education.

2. The level of math attempted at Leaving Certificate level among those who made the transition to an academic route at upper second level. This variable distinguishes between (a) students who pursued higher level math (higher math or higher/lower applied math) at upper secondary, (b) those who pursued lower math levels (math at ordinary or foundation level) at upper secondary, and (iii) those who did not complete upper secondary education.

3. The type of higher education pursued beyond second level. It is also possible to make a distinction between the type of educational institution attended by full-timers and part-timers among those who pursued the academic track at upper secondary. This variable distinguishes between those who transitioned to (a) university (b) institute of technology and other third-level colleges, and (c) those who did not make the transition to tertiary education.

A number of social background variables relevant to the identification of theoretically focal persons are included as independent variables in the model. These include the following:

- Parental social class which was derived using the classification from the 1986 Census Classification of Occupations leading to the following groups: higher professional, lower professional, nonmanual, skilled manual, skilled, and semiskilled manual, unskilled manual, farmers. In this article, farmers are merged with higher and lower professional groups, because of their similar postschool outcomes. A "dominance approach" (Erikson, 1984) is used in the definition of social class. Thus, social class is based on the mother's rather than the father's position if she is in employment and has a higher social class than her husband.

- Attendance at different types of schools. This variable distinguishes between students who attended a secondary, community/comprehensive, or vocational school at second level. In addition to ownership and patronage, the three types of school sectors differ in their student composition, with a greater concentration of working class and students with literacy, numeracy and behavioral difficulties attending vocational schools, and a higher concentration of middle-class students attending secondary schools (Byrne \& Smyth, 2010; Smyth, 1999).

- Family structure, distinguishing between lone-parent family and two-parent family types.

In addition, a range of independent variables have also been included in the analyses. These include the following:

- Gender, distinguishing between females and males

- Household employment situation, distinguishing between "work-rich" and "work-poor" households based on the number of parents present and the economic situation of the family. A work-poor household represents a household 
with full household unemployment, irrespective of the number of parents present. Household employment situation is not used as a socioeconomic background variable as parental employment situation is used when devising the dominance approach to social-class classification.

- Previous educational performance for those who completed the Leaving Certificate from 1984 onward. This variable represents a grade point average (GPA) that has been normalized and centered on the mean.

All control variables are set to the modal category for categorical variables, and the mean category for continuous variables. Due to missing data on key variables including school type and parental social class, survey years for the following cohorts were omitted from the analyses: Cohort 1 (1983, 1984); Cohort $2(1988,1993,1994)$ and Cohort 3 (2002). Analysis of missing data across variables revealed that listwise deletion of missing data would have resulted in a considerable reduction in the sample size. To avoid this problem, the models include additional terms for missing cases when necessary, allowing a direct test of the probabilities of the groups with missing data on explanatory variables. This allows an examination of the extent to which variables have nonrandom missing data.

\section{Analytic Strategy}

The models are estimated using ordered logit regression models, with tests for parallel lines. When the tests for parallel lines are violated, generalized ordered regression models are used instead. All analyses were conducted using STATA. Central to the test of EMI is the choice of theoretically focal persons. Thus, the predicted probabilities from each equation are calculated by taking the sample average (the mode for categorical variables and the mean for scale variables) of all variables under construction. These average values are listed as follows: parental social class (skilled manual); school type (community/comprehensive), household employment (work in the household); gender (female); family structure (two-parent household); GPA; and type of math pursued for upper secondary examination (lower/ordinary). As in the original article by Lucas (2001), we examine several tests of separate dimensions of socioeconomic background, and then, a final test that considers multiple variables simultaneously. In doing so, we compare the distribution of predicted probabilities for advantaged and disadvantaged theoretically focal persons to test EMI. EMI exists when advantaged and disadvantaged persons do not have the same modal category of outcome. EMI does not exist when advantaged and disadvantaged persons have the same modal category of outcome. For the purpose of the analyses presented here, advantaged students can be classified as those whose parents are members of the higher or lower professional and farming social-class groups, two-parent families, and those who have attended a secondary school. Disadvantaged students can be classified as those from an unskilled manual backgrounds, single-parent families, and those who have attended a vocational school. 


\section{Results}

\section{Transition I: Transition From Junior to Senior Cycle (All School Leavers)}

Table 2 reports the results of a generalized ordered logit model predicting the type of upper second-level education that young people pursued for each of the three cohorts under investigation. The last three columns in Table 2 refer to the relative chances of being in an academic upper secondary program specifically, rather than a prevocational program or not being in upper secondary education at all. Here, we find that parental social class, gender, and household employment situation each are significant predictors of attending an academic track. These effects are relatively stable across each of the three cohorts, spanning from the late 1970s to the mid-2000s. Over time, we see some change with regard to the pathways of children from semiskilled manual backgrounds: while the earlier cohort were more likely to in be in an academic upper secondary program (when the Preemployment Program was in existence), there was no significant difference between skilled manual and semiskilled manual groups in later cohorts. This suggests that the semiskilled manual group may have been negatively influenced by changes in the provision of school-based vocational education than any other group. Interesting changes are also evident with regard to the type of school attended: clear differences emerge over the cohorts according to school type. For the earlier cohorts, those attending secondary schools were more likely to be in an academic program than not, while those attending vocational schools were less likely to be in an academic track, reflecting the historical development of school sectors in the Irish context. By Cohort 3, school type did not emerge as a significant predictor of curriculum differentiation at upper second level, reflecting the greater provision of the current prevocational program, the Leaving Certificate Applied, across all school types than earlier programs.

Table 3 presents the regression coefficients as predicted probabilities for participating in different types of programs at upper secondary level for those from high- and low-socioeconomic backgrounds with regard to parental social class, school type, family structure, and multiple dimensions of socioeconomic background taken together. The first contrast relates to those whose parents are from a higher professional/farming background versus those whose parents are from an unskilled manual background. The same general pattern is evident across cohorts; those from more advantaged class backgrounds are most likely to be in academic programs for each of the three cohorts, while those from more disadvantaged backgrounds are most likely to have not made the transition to upper secondary level. It is clear that social-class background is strongly related to track location in the Irish context. The second contrast relates to those who attend secondary versus vocational schools. We find that the results differ by cohort when examined by school type. Consistent somewhat with the findings of our regression models, only for the earlier cohort do advantaged and disadvantaged persons not have the same modal category of outcome. Thus, EMI is evident for Cohort 1, but does not exist when advantaged and disadvantaged persons have the same modal category of outcome in Cohort 2 and Cohort 3. As before, this is likely to 


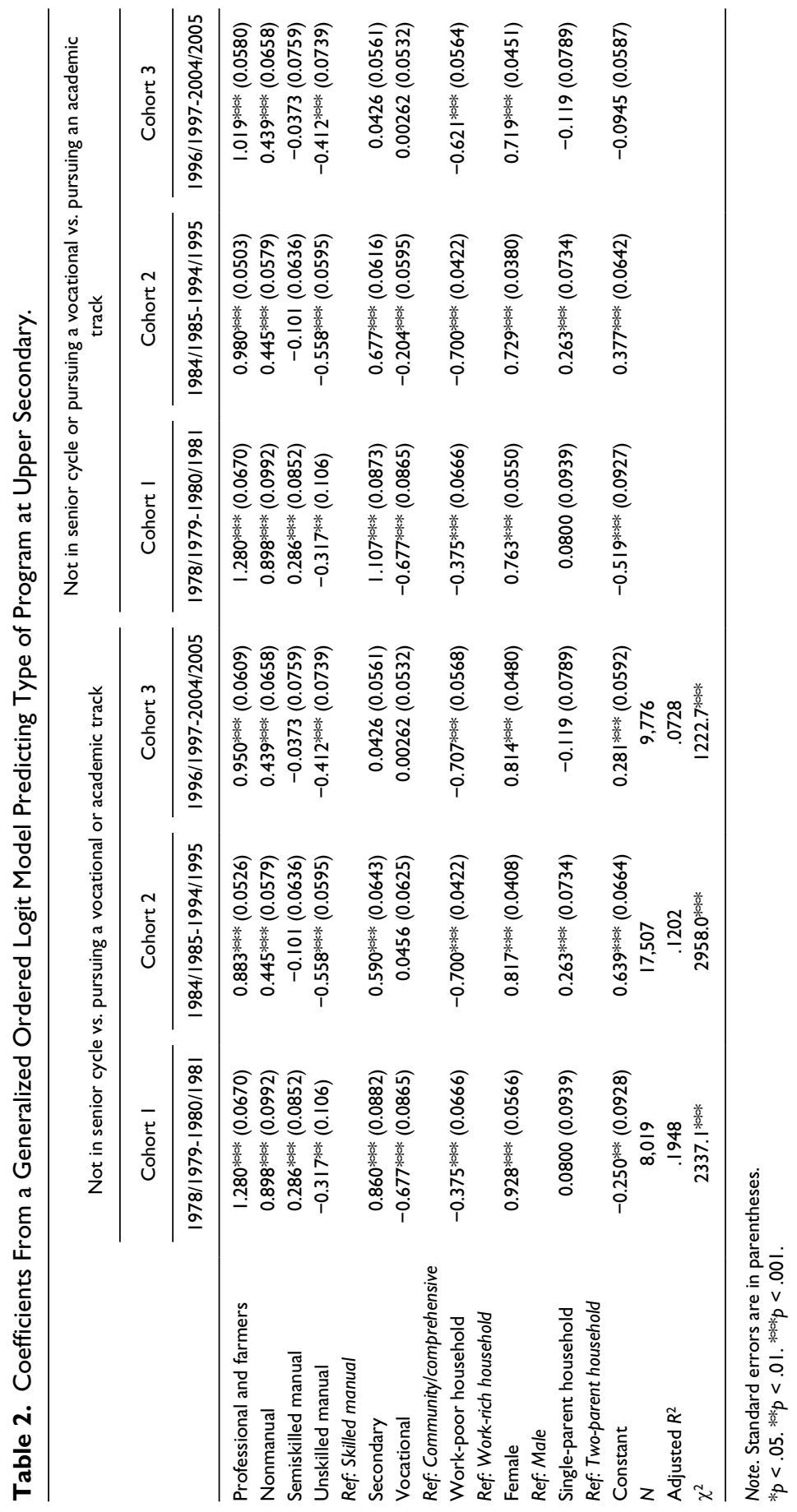


Table 3. Predicted Probabilities From a Generalized Ordered Logit Model Predicting Type of Program at Upper Secondary.

\begin{tabular}{|c|c|c|c|c|c|c|}
\hline & \multicolumn{2}{|c|}{ Cohort I } & \multicolumn{2}{|c|}{ Cohort 2} & \multicolumn{2}{|c|}{ Cohort 3} \\
\hline & Advantaged & Disadvantaged & Advantaged & Disadvantaged & Advantaged & Disadvantaged \\
\hline \multicolumn{7}{|c|}{ Parental social class (professional/farming vs. unskilled manual) } \\
\hline $\begin{array}{l}\text { Not in } \\
\text { senior cycle }\end{array}$ & 0.263 & 0.638 & 0.179 & 0.479 & 0.226 & 0.532 \\
\hline Vocational & 0.055 & 0.059 & 0.025 & 0.065 & 0.057 & 0.091 \\
\hline Academic & $0.68 I$ & 0.302 & 0.795 & 0.455 & 0.716 & 0.376 \\
\hline \multicolumn{7}{|c|}{ School type (secondary vs. vocational) } \\
\hline $\begin{array}{l}\text { Not in } \\
\text { senior cycle }\end{array}$ & 0.352 & 0.716 & 0.226 & 0.335 & 0.419 & 0.429 \\
\hline Vocational & 0.005 & 0.051 & 0.032 & 0.121 & 0.093 & 0.093 \\
\hline Academic & 0.642 & 0.232 & $0.74 I$ & 0.543 & 0.487 & 0.477 \\
\hline \multicolumn{7}{|c|}{ Family Structure (Two-parent vs Single-parent family) } \\
\hline $\begin{array}{l}\text { Not in } \\
\text { senior cycle }\end{array}$ & 0.562 & 0.542 & 0.345 & 0.288 & 0.430 & 0.459 \\
\hline Vocational & 0.064 & 0.065 & 0.061 & 0.056 & 0.093 & 0.093 \\
\hline Academic & 0.373 & 0.392 & 0.593 & 0.654 & 0.476 & 0.446 \\
\hline \multicolumn{7}{|c|}{ Advantaged vs. disadvantaged } \\
\hline $\begin{array}{l}\text { Not in } \\
\text { senior cycle }\end{array}$ & 0.131 & 0.762 & 0.108 & 0.403 & 0.218 & $0.56 I$ \\
\hline Vocational & 0.002 & 0.045 & 0.007 & 0.126 & 0.056 & 0.089 \\
\hline Academic & 0.866 & 0.192 & 0.884 & 0.469 & 0.724 & 0.349 \\
\hline
\end{tabular}

Note. Bold text indicates the modal category(ies).

reflect the greater provision of recent prevocational programs across all school types than the earlier preemployment course which tended to be provided in vocational schools. In the third contrast, EMI is not found when family structure is taken into account. However, when multiple dimensions of socioeconomic background are taken into consideration in the final contrast, there is clear evidence of EMI. That is, students from advantaged backgrounds are most likely to be found in the academic track while students from less advantaged backgrounds are most likely to be found without an upper secondary academic qualification for each of the three cohorts. Irrespective of the different configurations of prevocational education in the curriculum, socially advantaged parents are better placed to secure more advantageous routes for their children. Our analyses show that altering the students' social-class status changes the prediction for their track location persistently across cohorts. That being said, recent curricular developments in the area of prevocational education have reduced the difference in the predicted probabilities between the two groups (see Table 4). However, the stark contrast between socioeconomically disadvantaged and advantaged students is consistent with EMI and is maintained as school completion rates increase. Thus, it suggests that when a level of education is universal, social background does matter for qualitative dimensions of education and are likely to have implications for students' chances of making later transitions. 
Table 4. Difference in Predicted Probabilities of Being in an Academic Track, All Cohorts.

\begin{tabular}{lccc}
\hline & \multicolumn{2}{c}{ Predicted probabilities of being in an academic track } \\
\cline { 2 - 4 } Focal persons & Advantaged & Disadvantaged & Difference \\
\hline Cohort I & 0.866 & 0.192 & 0.7 \\
Cohort 2 & 0.884 & 0.469 & 0.4 \\
Cohort 3 & 0.724 & 0.349 & 0.4 \\
\hline
\end{tabular}

\section{Transition 2: Subject Differentiation in Level of Math Completed, Academic Track Students Only}

Our second transition point then follows academic track students as they progress to completion of upper secondary education, while exploring the effects of subject-level differentiation in math. Table 5 reports the results of a generalized ordered logit model predicting the level of math completed at upper secondary education by academic track students. Again, we find a considerable effect of parental social class: those whose parents are from higher/lower professional and farming backgrounds are consistently, and what seems like increasingly more likely to have completed honors math over time (1.7 times more likely in Cohort 1 to 2.4 times more likely by Cohort 3 ). As the share of academic track students opting for higher level math increased in real terms over the period (from $10 \%$ of Cohort 1 to $16 \%$ of Cohort 3 ), it appears that the unskilled manual group became less likely to have taken honors math. This was also true among those who came from work-poor households. In terms of school effects, as the share of academic track students opting for higher level math increased over time, the advantage of attending a secondary school on the probability of taking higher level math declines and by Cohort 3 was no longer significant. However, the relative disadvantage of attending a vocational school continued, as students attending vocational schools were significantly less likely to have completed honors math across each of the three cohorts.

The predicted probabilities for the most disadvantaged and most advantaged students for each of the four socioeconomic variables, holding all remaining variables constant are presented in Table 6. When multiple dimensions of socioeconomic background are taken into consideration in the final contrast, there is evidence to suggest that altering the students' socioeconomic status would change the outcome prediction, but for the most recent cohort only. That is, among Cohort 3, we find that advantaged students are found in "lower level math" while disadvantaged students are almost equally found "not to be in senior cycle" or in "lower level math," reflecting support for EMI. It would seem that the role of parental social class has become increasingly important over time in the predicted probability of taking higher level math, as the gap between advantaged and disadvantaged groups widens (see Table 7). Furthermore, this has occurred as the share of academic track students opting for higher level math has been on the increase. 


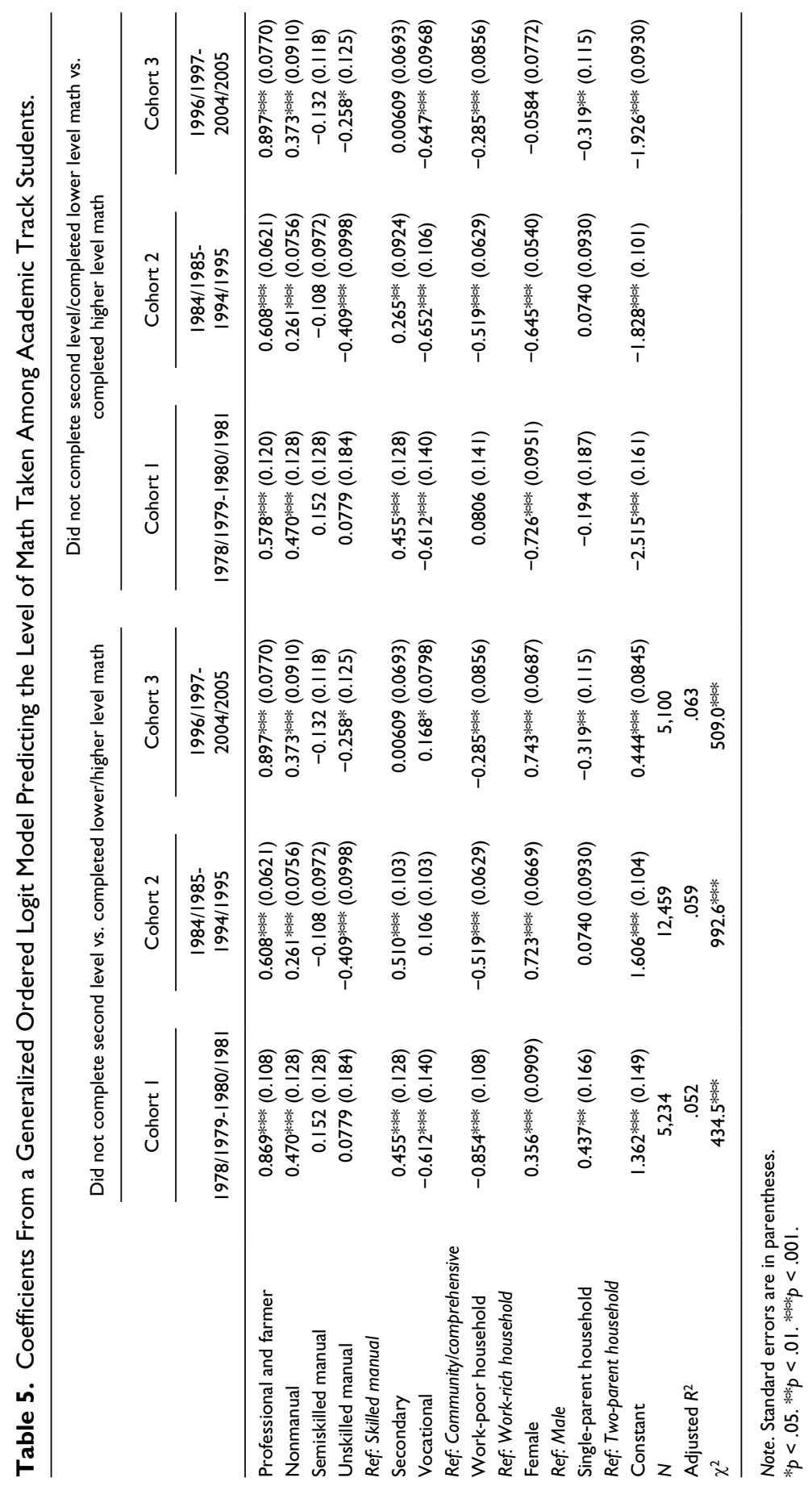


Table 6. Predicted Probability From a Generalized Ordered Logit Model Predicting the Level of Math Taken Among Academic Track Students.

\begin{tabular}{|c|c|c|c|c|c|c|}
\hline & \multicolumn{2}{|c|}{ Cohort I } & \multicolumn{2}{|c|}{ Cohort 2} & \multicolumn{2}{|c|}{ Cohort 3} \\
\hline & Advantaged & Disadvantaged & Advantaged & Disadvantaged & Advantaged & Disadvantaged \\
\hline \multicolumn{7}{|c|}{ Parental social class (professional and farmer vs. unskilled manual) } \\
\hline $\begin{array}{l}\text { Not in senior } \\
\text { cycle }\end{array}$ & 0.096 & 0.191 & 0.102 & 0.226 & 0.207 & 0.453 \\
\hline $\begin{array}{l}\text { Lower level } \\
\text { math }\end{array}$ & 0.776 & 0.728 & 0.665 & 0.686 & 0.529 & 0.445 \\
\hline $\begin{array}{l}\text { Higher level } \\
\text { math }\end{array}$ & 0.126 & 0.080 & 0.231 & 0.087 & 0.263 & 0.101 \\
\hline \multicolumn{7}{|c|}{ School type (secondary vs. vocational) } \\
\hline $\begin{array}{l}\text { Not in senior } \\
\text { cycle }\end{array}$ & 0.139 & 0.320 & 0.100 & 0.144 & 0.389 & 0.351 \\
\hline $\begin{array}{l}\text { Lower level } \\
\text { math }\end{array}$ & 0.747 & 0.637 & 0.738 & 0.783 & 0.482 & 0.577 \\
\hline $\begin{array}{l}\text { Higher level } \\
\text { math }\end{array}$ & 0.113 & 0.042 & 0.161 & 0.071 & 0.127 & 0.070 \\
\hline \multicolumn{7}{|c|}{ Family Structure (Two parent v Single parent family) } \\
\hline $\begin{array}{l}\text { Not in senior } \\
\text { cycle }\end{array}$ & 0.203 & 0.141 & 0.158 & 0.148 & 0.390 & 0.468 \\
\hline $\begin{array}{l}\text { Lower level } \\
\text { math }\end{array}$ & 0.721 & 0.795 & $0.7 I I$ & 0.712 & 0.482 & 0.435 \\
\hline $\begin{array}{l}\text { Higher level } \\
\text { math }\end{array}$ & 0.048 & 0.062 & 0.129 & 0.138 & 0.127 & 0.095 \\
\hline \multicolumn{7}{|c|}{ Advantaged vs. disadvantaged } \\
\hline $\begin{array}{l}\text { Not in senior } \\
\text { cycle }\end{array}$ & 0.063 & 0.220 & 0.063 & 0.195 & 0.206 & 0.491 \\
\hline $\begin{array}{l}\text { Lower level } \\
\text { math }\end{array}$ & 0.750 & 0.742 & 0.656 & 0.753 & 0.529 & 0.467 \\
\hline $\begin{array}{l}\text { Higher level } \\
\text { math }\end{array}$ & 0.185 & 0.037 & 0.280 & 0.051 & 0.264 & 0.041 \\
\hline
\end{tabular}

Note. Bold text indicates the modal category(ies).

\section{Transition 3: Transition to Postschool Pathways}

The final transition follows academic track students who completed upper secondary education into their postschool outcomes. The last three columns in Table 8 refer to the relative chances of attending a university versus any other postschool outcome. Again, we find that social class is a significant predictor of attending university higher education with similar patterns across each of the three cohorts. Those whose parents are from higher and lower professional, farming, and nonmanual backgrounds are more likely to have attended university higher education for each of the three cohorts. This is also true of academic track students who took higher level math, while those attending vocational schools are less likely to have attended university compared with community/comprehensive students. 
Table 7. Difference in Predicted Probabilities of Being in a Higher Level Math Class, All Cohorts.

\begin{tabular}{lccc}
\hline & Advantaged & Disadvantaged & Difference \\
\hline $\begin{array}{l}\text { Cohort I } \\
\text { Parental social class }\end{array}$ & 0.126 & & \\
School type & 0.113 & 0.08 & 0.0 \\
Family structure & 0.048 & 0.042 & 0.1 \\
All & 0.185 & 0.062 & 0.0 \\
Cohort 2 & & 0.037 & 0.1 \\
Parental social class & 0.231 & & \\
School type & 0.161 & 0.087 & 0.1 \\
Family structure & 0.129 & 0.071 & 0.1 \\
All & 0.28 & 0.138 & 0.0 \\
Cohort 3 & & 0.051 & 0.2 \\
Parental social class & 0.263 & & 0.2 \\
School type & 0.127 & 0.101 & 0.1 \\
Family structure & 0.127 & 0.07 & 0.0 \\
All & 0.264 & 0.095 & 0.2 \\
\hline
\end{tabular}

Table 9 presents a similar analysis, but includes GPA to provide a better comparison of like with like for Cohorts 2 and 3. Again, we find that social class is a significant predictor of being in university higher education with similar patterns across each of the three cohorts. However, a more direct comparison of like with like reveals that only for Cohort 2 are those from unskilled manual backgrounds less likely be in university education than those from skilled manual backgrounds, all else being equal. In this model, school effects are enhanced: attending a secondary school is associated with a greater probability of attending university, while attending a vocational school is associated with a greater probability of not attending university for each of the two cohorts. While university attendance was influenced by household employment situation among earlier cohorts, Cohort 3 which can be characterized by the removal of higher education tuition fees reveals that household employment situation does not influence university attendance, all else being equal. The influence of earlier streaming is also evident: The positive influence of pursuing honors math in senior cycle on university attendance is clear, and those with average/higher GPAs are more likely to be in university higher education than not.

When the regression coefficients previously presented in Table 9 are translated into predicted probabilities of the different types of postschool outcomes, evidence for EMI is found for Cohort 2 but not for the more recent Cohort 3 (see Table 10). Among Cohort 2, in every case altering the students' socioeconomic status would change the prediction for the postschool destination. That is, students from high-socioeconomic backgrounds are more likely to be found participating in university while students from low-socioeconomic backgrounds are more likely to be found attending an institute of technology or college. This "diverging trajectories" pattern holds for all of the 


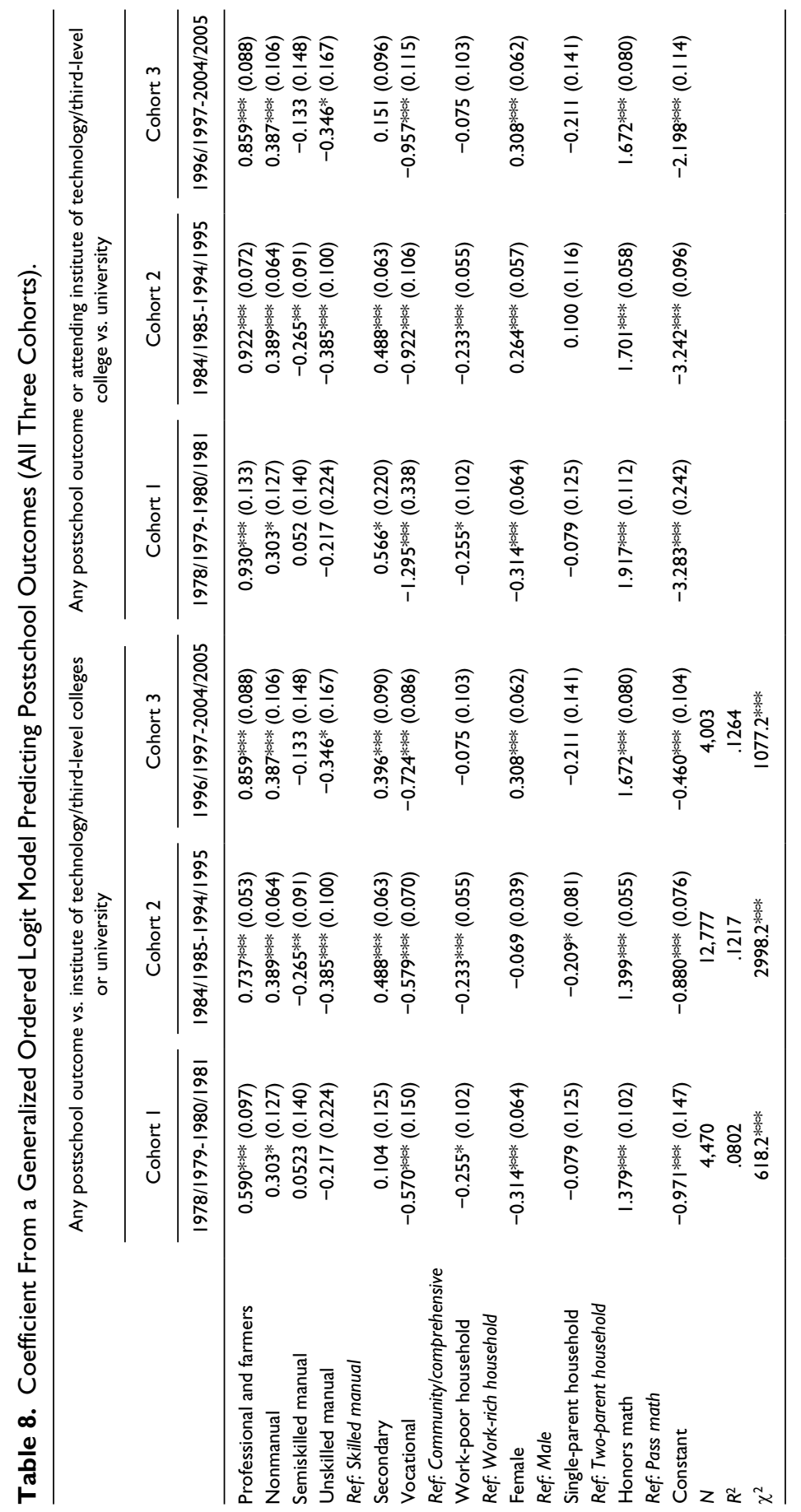




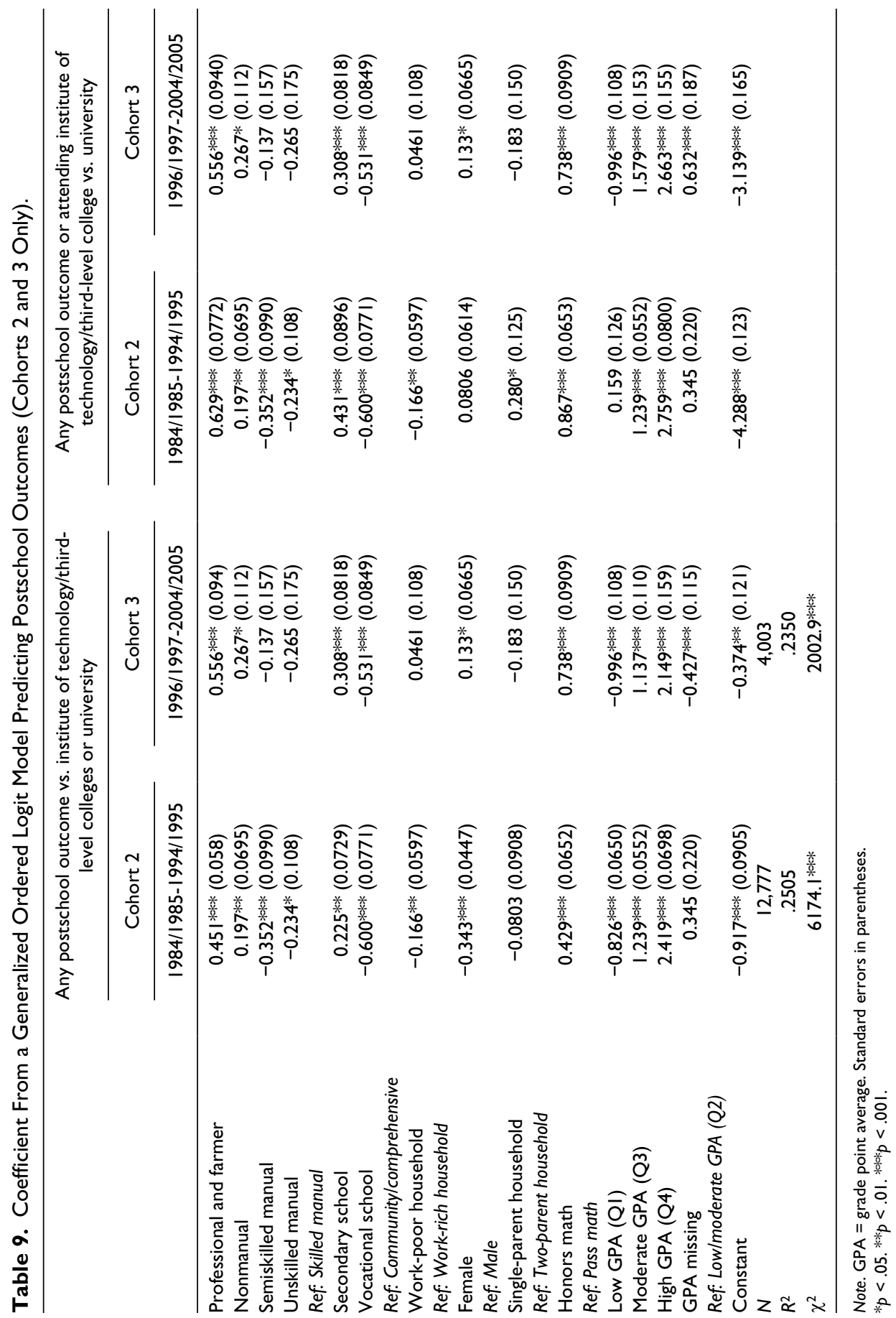


Table 10. Predicted Probabilities From a Generalized Ordered Logit Model Predicting Postschool Outcomes (Cohorts 2 and 3 Only).

\begin{tabular}{|c|c|c|c|c|}
\hline & \multicolumn{2}{|c|}{ Cohort 2} & \multicolumn{2}{|c|}{ Cohort 3} \\
\hline & Advantaged & Disadvantaged & Advantaged & Disadvantaged \\
\hline \multicolumn{5}{|l|}{$\begin{array}{l}\text { Parental social class } \\
\text { (professional/farmer vs. } \\
\text { unskilled manual) }\end{array}$} \\
\hline Not in education & 0.039 & 0.075 & 0.033 & 0.069 \\
\hline $\begin{array}{l}\text { Institute of technology } \\
\text { and other third level }\end{array}$ & 0.376 & 0.552 & 0.108 & 0.224 \\
\hline University & 0.583 & 0.371 & 0.858 & 0.705 \\
\hline \multicolumn{5}{|c|}{ School type (secondary vs. vocational) } \\
\hline Not in education & 0.048 & 0.105 & 0.037 & 0.086 \\
\hline $\begin{array}{l}\text { Institute of technology } \\
\text { and other third level }\end{array}$ & 0.415 & 0.603 & 0.160 & 0.261 \\
\hline University & 0.535 & 0.291 & 0.802 & 0.652 \\
\hline \multicolumn{5}{|l|}{ Family structure } \\
\hline Not in education & 0.060 & 0.065 & 0.055 & 0.066 \\
\hline $\begin{array}{l}\text { Institute of technology } \\
\text { and other third level }\end{array}$ & $0.5 \mathrm{II}$ & 0.437 & 0.169 & 0.186 \\
\hline University & 0.427 & 0.497 & 0.774 & 0.746 \\
\hline \multicolumn{5}{|c|}{ Advantaged vs. disadvantaged } \\
\hline Not in education & 0.031 & 0.138 & 0.021 & 0.126 \\
\hline $\begin{array}{l}\text { Institute of technology } \\
\text { and other third level }\end{array}$ & 0.284 & 0.560 & 0.100 & 0.344 \\
\hline University & 0.683 & 0.300 & 0.877 & 0.528 \\
\hline
\end{tabular}

Note. Bold text indicates the modal category(ies).

social-class background factors considered (with regard to parental social class, school type attended, family structure). When we examine the multiple dimensions of socioeconomic background, this comparison which reflects some degree of association between these indicators of social background, show that we would predict the disadvantaged student to be in any third-level institution other than a university.

\section{Conclusion}

While the role of social class on young people's trajectories has been well established in the empirical literature in the Irish context, less attention has been paid to the study of qualitative distinctions at the same level of education over time, and how young people from different social-class backgrounds fare. This article shows that as students move through the education system, they transition through qualitatively different educational experiences, at the same level of education. Social-class and the socioeconomic backgrounds of young people influence not only the probability of making it 
through the education system but also their location in the curriculum, with implications for future transitions.

In our examination of the extent to which social class is related to students' progression along qualitatively differentiated pathways in Ireland, we sought to examine social-class inequalities across multiple transitions and cohorts reflecting considerable distinct periods of curricular and economic change. As a result, we find three notable patterns to support the hypothesis of EMI:

- considerable evidence to support the persistence of EMI in tracking decisions made in the transition from lower to upper secondary education for each of the three cohorts

- emerging patterns to support EMI with regard to subject-level differentiation in the upper secondary math curriculum for Cohort 3

- a declining pattern of EMI with regard to accessing university higher education between Cohort 2 and Cohort 3.

These patterns are particularly evident when multiple indicators of socioeconomic status (parental social class, school type attended and family structure) are considered simultaneously.

With regard to track location at upper secondary education, there is clear evidence to support EMI for each of the three cohorts representing young people who left the second-level education system between 1978/1979 and 2004/2005. That is, when multiple indicators of socioeconomic status are considered simultaneously for each of the three cohorts; students from advantaged backgrounds are most likely to be found in the academic track while students from disadvantaged backgrounds are most likely to be found without an upper secondary academic qualification, irrespective of the version of prevocational education on offer. Thus, the prevocational elements of the curriculum have had the effect of maintaining social-class inequality. That being said, recent curricular developments in the area of prevocational education have reduced the difference in the predicted probabilities between the two focal groups. However, it is important to bear in mind that we also present evidence to show that the semiskilled manual group has been disproportionately negatively affected by these curricular changes as they have become more likely to attend vocational rather than academic pathways over time.

This article also reveals increasing inequality with regard to subject-level differentiation in the upper secondary math curriculum. While there was no evidence to suggest the existence of EMI among the earlier cohorts, a growth in the share of young people pursuing higher level math, and an increasingly present high-stakes culture associated with the terminal examination of second level reveals a pattern of EMI among those who left school between 1996 and 2005 (Cohort 3). Our analyses also showed that the role of parental social class has become increasingly important over time in the predicted probability of taking higher level math, as the gap between advantaged and disadvantaged groups widens (see Table 7). It is important to bear in mind that the multivariate analyses also show that unskilled manual group and those 
from work-poor households became less likely to take honors math as the share of young people pursuing higher level math rose. These patterns are likely to be exacerbated by the recent policy decision in 2012 to make changes to the point allocation for math in the Leaving Certificate. As a result, students who pass higher level math are awarded "bonus points" for university entry.

Our analyses also reveal the effects of inequality on postschool destinations. That is, altering the students' socioeconomic status would change the prediction for the postschool destination but for the earlier cohort only (Cohort 2). Academic track students from high-socioeconomic backgrounds were more likely to be found participating in university while students from low-socioeconomic backgrounds were more likely to be found attending an institute of technology or college. However, there was no evidence of EMI for the most recent cohort. While the established empirical literature indicates that the removal of tuition fees has not had any substantial impact on reducing social-class inequality in higher education participation, this article shows that altering a students' socioeconomic status does change the outcome prediction when tuition fees were in play (Cohort 2). It may well be that the removal of tuition fees for higher education by Cohort 3 has had some impact on the postschool destinations of those who had pursued an academic track at upper secondary education. As a result, academic track students from low-socioeconomic backgrounds were able to "move over the threshold" in Cohort 3 (Lucas, 2001). As the Irish Government currently debates the reintroduction of tuition fees at higher education (accompanied by a student loan scheme), these analyses suggest that any such policy decision is likely to generate social-class inequality, given the absence of any large-scale reform of the system of (financial) supports for students from lower social class backgrounds.

In the past, it has been highlighted that the Irish state has played a key role in expanding the educational system (O'Riain \& O'Connell, 2000). The patterns of social-class inequality over a 30 -year period presented in this article suggest that qualitative differences at the same level of education represent a key barrier to greater equality in the Irish context. That is, the welfare state and educational policies (policies around tracking, subject-level differentiation and differentiation in higher education, and the costs of attending higher education) are likely to reproduce inequality. These effects are important to consider at a time when continued expansion in second level and higher education is anticipated over the coming decade (Department of Education and Skills, 2012; McGuinness et al., 2012).

\section{Declaration of Conflicting Interests}

The author(s) declared no potential conflicts of interest with respect to the research, authorship, and/or publication of this article.

\section{Funding}

The author(s) received the following financial support for the research, authorship, and/or publication of this article: The authors gratefully acknowledge receipt of a travel grant from the 
EqualSoc Network of Excellence (Economic Change, Quality of Life and Social Cohesion) to support this research.

\section{Notes}

1. More recently, school completion rates have reached just over $90 \%$ (Department of Education and Skills, 2015).

2. For a more detailed discussion of distinctions between programs, see Byrne (2008) and Banks et al. (2010).

3. Data exclude VPT2, which represents a postschool vocational course.

4. For exceptions, see Smyth and Hannan (2002) and Sofroniou, Archer, and Weir (2004).

5. These estimates are based on estimates from the SLS, and are very much in line with data published by the Department of Education and Skills in their annual statistical surveys.

\section{References}

Banks, J., Byrne, D., McCoy, S., \& Smyth, E. (2010). Engaging young people? Student experiences of the Leaving Certificate Applied (ESRI Research Series No. 15). Retrieved from https://www.esri.ie/pubs/RS015.pdf

Banks, J., Byrne, D., McCoy, S., \& Smyth, E. (2014). Bottom of the class? The Leaving Certificate Applied programme and track placement in the Republic of Ireland. Irish Educational Studies, 33, 351-366.

Beblavý, M., Thum, A., \& Veselkova, M. (2013). Education and social protection policies in OECD countries: Social stratification and policy intervention. Journal of European Social Policy, 23, 487-503.

Breen, R., Luijkx, R., Muller, W., \& Pollack, R. (2009). Nonpersistent inequality in educational attainment: Evidence from eight European countries. American Journal of Sociology, 114, $1475-1521$.

Breen, R., \& Whelan, C. (1993). From Ascription to Achievement? Origins, Education and Entry to the Labour Force in the Republic of Ireland during the Twentieth Century. Acta Sociologica, 36(1), 3-17

Byrne, D. (2008). The influence of early work experiences undertaken before leaving second level education on the socio-economic outcomes of school leavers in the Republic of Ireland. Edinburgh, Scotland: Centre for Educational Sociology, University of Edinburgh.

Byrne, D. (2009). Inclusion or diversion in higher education in the Republic of Ireland? (ESRI Working Paper No. 304). Retrieved from http://sinche.uom.gr/sites/default/files/byrne.pdf

Byrne, D., McCoy, S., \& Watson, D. (2008). School Leavers' Survey Report 2007. Dublin, Ireland: Economic and Social Research Institute.

Byrne, D., \& Smyth, E. (2010). Behind the scenes? A study of parental involvement in secondlevel education. Dublin, Ireland: Liffey Press.

Department of Education and Skills. (2012). Projections of full-time enrolment: Primary and second level, 2012-2030. Retrieved from https://www.education.ie/en/Publications/ Statistics/Projections-of-full-time-enrolment-Primary-and-Second-Level-2012-2030.pdf

Department of Education and Skills. (2015). Retention rates of pupils in second level schools: 2008 Entry cohort Dublin. Dublin, Ireland: Stationery House.

Erikson, R. (1984). Social class of men, women and families. Sociology, 18, 500-514.

Esping-Andersen, G. (1990). The three worlds of welfare capitalism. Cambridge, England: Polity Press. 
Hall, P. A., \& Soskice, D. (2001). Varieties of capitalism: The institutional foundations of comparative advantage. Oxford, England: Oxford University Press.

Hannan, D., Raffe, D., \& Smyth, E. (1997). Cross-national research on school to work transitions: An analytic framework. In P. Werquin, R. Breen, \& J. Plans (Eds.), Youth transitions in Europe: Theories and evidence (pp. 409-442). Marseille, France: CEREQ.

Kelly, E., O'Connell, P. J., \& Smyth, E. (2010). The economic returns to field of study and competencies among higher education graduates in Ireland. Economics of Education Review, 29, 650-657.

Layte, R., O'Connell, P. J., Fahey, T., \& McCoy, S. (2005). Ireland and economic globalization: The experiences of a small open economy. In H. P. Blossfeld, E. Klijzing, M. Mills, \& K. Kurz (Eds.), Globalization, uncertainty and youth in society (pp. 403-422). New York, NY: Routledge.

Lucas, S. R. (2001). Effectively maintained inequality: Education transitions, track mobility, and social background effects. American Journal of Sociology, 106, 1642-1690.

Lucas, S. R. (2009). Stratification theory, socioeconomic background, and educational attainment: A formal analysis. Rationality and Society, 21, 459-511.

Mau, S., \& Verwiebe, R. (2010). European societies: Mapping structure and change. Bristol, England: Policy Press.

McCoy, S., \& Byrne, D. (2010). Non progression among higher education new entrants: A multivariate analysis. In V. Patterson, O. Mooney, M. O'Connor, \& A. Chantler (Eds.), A study of progression in higher education (pp. 40-53). Dublin, Ireland: Higher Education Authority.

McCoy, S., \& Smyth, E. (2011). Higher education expansion and differentiation in the Republic of Ireland. Higher Education, 61, 243-260.

McCoy, S., Smyth, E., Watson, D., \& Darmody, M. (2014). Leaving school in Ireland: A longitudinal study of post-school transitions (ESRI Research Series No. 36). Retrieved from https://www.esri.ie/pubs/RS36.pdf

McGuinness, S., Bergin, A., Kelly, E., McCoy, S., Smyth, E., \& Timoney, K. (2012). A study of future demand for higher education in Ireland (ESRI Research Series No. 30). Dublin, Ireland: Economic and Social Research Institute.

Nolan, B., Whelan, C. T., Calvert, E., Fahey, T., Healy, D., Mulcahy, A., ... Winston, N. (2014). Ireland: Inequality and its impacts in bust and boom. In B. Nolan, W. Salverda, D. Checci, I. Marx, A. McKnight, I. Gyorgy Toth, \& H. van der Werfhorst (Eds,), Changing inequalities and societal impacts in rich countries: Thirty countries' experiences (pp. 346368). Oxford, England: Oxford University Press.

Organisation for Economic Co-operation and Development. (2013). Education at a Glance 2013: OECD Indicators. Paris, France: Author.

O'Riain, S., \& O'Connell, P. (2000). The role of the state in growth and welfare. In B. Nolan, P. O'Connell, \& C. T. Whelan (Eds.), Bust to boom? The Irish experience of growth and inequality (pp. 310-339). Dublin, Ireland: Institute of Public Administration.

Pechar, H., \& Lesley, A. (2011). Higher-Education Policies and Welfare Regimes: International Comparative Perspectives. Higher Education Policy, 24, 25-52.

Smyth, E. (1999). Do Schools Differ? Academic and Personal Development among Pupils in the Second-Level Sector. Dublin: Oak Tree Press in association with The Economic and Social Research Institute.

Smyth, E., \& Hannan, C. (2002). Who chooses science? Subject take-up in second level schools. Dublin, Ireland: Liffey Press. 
Sofroniou, N., Archer, P., \& Weir, S. (2004). An analysis of the association between socioeconomic context, gender and achievement. Irish Journal of Education, 35, 58-72.

Whelan, C. T., \& Layte, R. (2002). Late Industrialisation and the Increased Merit Selection Hypothesis: Ireland as a Test Case. European Sociological Review, 18(1), 33-50.

\section{Author Biographies}

Delma Byrne is a Lecturer in Sociology of Education and Social Inequality at Maynooth University Departments of Sociology and Education. Her main research interests focus on social stratification and the role of education in shaping life chances, cross-cutting matters of gender, social class, migration, race/ethnicity and disability.

Selina McCoy is an Associate Research Professor at the Economic and Social Research Institute and Adjunct Professor at Trinity College Dublin. Her main areas of research are educational inequality, post-school transitions and special educational needs. 